\title{
Nobelova cena za ekonomii pro otce hypotézy o efektivních trzích
}

Vážení čtenáři,

stoupenci teorie efektivních trhů se konečně dočkali a já mezi nimi. Eugene F. Fama z University of Chicago získal 14. října 2013 Nobelovu cenu za ekonomii! Tedy přesněji Cenu Švédské národní banky za rozvoj ekonomické vědy na památku A. Nobela. Otec teorie efektivního trhu E. F. Fama předpokládá, že akciové kursy jsou ovlivňovány jak fundamentálními, tak i nefundamentálními kursotvornými informacemi. Za efektivní je pak Famou považován takový likvidní akciový trh, který velmi rychle a přesně absorbuje všechny podstatné neočekávané kursotvorné informace. Tržní cena akcií na likvidním trhu představuje správnou hodnotu, akcie jsou obvykle správně oceněny a na trhu prakticky nelze najít podhodnocené nebo nadhodnocené akciové tituly. Termín efektivní se tedy používá ve smyslu způsobu zpracování neočekávaných informací. Obrovský význam pro teorii efektivních trhů měla zejména práce Famy z roku $1965,{ }^{1}$ ve které dospěl k závěru, že akciové kursy se na americkém trhu s blue chips chovají náhodně. Tato práce se stala zlomem, od kterého se velmi často datuje vznik teorie efektivního trhu v americké literatuře. Empirický finanční výzkum Famy na Chicagské univerzitě se i v dalších dekádách především zaměřoval na testování hypotézy efektivního chování akciových trhü²

Teorie efektivních trhů vypadá na první pohled velmi logicky, přesvědčivě a elegantním způsobem dokáže vysvětlit chování akciových kursů. Famovské pojetí efektivních trhů nepředpokládá, že by investoři byli schopni bezchybně určit budoucí tržní cenu. Pouze tvrdí, že aktuální tržní cena je objektivní cenou, protože zahrnuje všechny dostupné kursotvorné informace. Tržní ceny akcií se pak chovají náhodně proto, poněvadž investoři neustále analyzují akciový trh, promítají nové kursotvorné informace do svého investičního rozhodování a snaží se dosáhnout maximálního výnosu vzhledem k riziku a likviditě. Investoři se tedy chovají racionálně, což pak také znamená, že i akciový trh vykazuje znaky racionální chování.

Akciové trhy mohou mít různou formu efektivnosti. Slabá forma efektivnosti znamená, že aktuální akciový kurs obsahuje všechny informace, které lze získat ze souborů historických dat. Proto investor nemůže $\mathrm{z}$ historických dat prognózovat budoucí kursový pohyb a změna akciového kursu je náhodná. Pokud nemůže být minulý trend použit pro predikování budoucího vývoje, pak ani teorie Charlese Dowa (tvořící teoretický základ technické akciové analýzy) nemůže objasnit podstatu chování akciových kursů. Za středně-silnou formu efektivnosti je považována situace, při které aktuální akciový kurs obsahuje nejen historická data, ale i velmi rychle a přesně reaguje na zveřejnění nových veřejných informací. Jestliže se akciové trhy chovají efektivně ve středně-silné formě, pak nelze na akciovém trhu objevit špatně oceněné investiční instrumenty. Při chování akciových trhů na úrovni středně-silné formy nemá smysl nejen technická akciová analýza, ale ani teorie vnitřní hodnoty akcie, tvořící jádro fundamentální akciové analýzy. Silná forma efektivnosti vyjadřuje skutečnost, že aktuální akciový kurs obsahuje všechny kursotvorné informace, tzn. jak veřejného, tak i neveřejného charakteru. Při této formě efektivnosti ztrácí význam nejen analytická činnost ve

1 Fama, E. F.: The Behavior of Stock Market Prices. Journal of Business, 1965, roč. 38, č. 1, s. 34-105.

2 Viz Fama, E. F.: Efficient Capital Markets: A Review of Theory and Empirical Work. Journal of Finance, 1970, roč. 25, č. 2, s. 383-417; Fama, E. F.: Efficient Capital Markets II. Journal of Finance, 1991, roč. 46, č. 2, s. 1575-1617; Fama, E. F.: Market Efficiency, Long-Term Returns and Behavioral Finance. Journal of Financial Economics, 1997, roč. 49, č. 3, s. 283-306. 
formě technické či fundamentální analýzy, ale bezcennými se stávají i neveřejné informace, poněvadž jsou již stejně absorbovány v akciovém kursu.

Teorie efektivních trhů představuje vysvětlení chování akciových kursů hlavním směrem současné moderní investiční ekonomie, která si však za svou „laboratoř“ zvolila především americký akciový trh jako největší, nejlikvidnější a nejrozvinutější akciový trh světa. Převážná většina významných světových investičních ekonomů se shoduje v názoru, že nejlikvidnější akcie na americkém akciovém trhu se chovají poměrně ekonomicky efektivně ${ }^{3}$. Je třeba si však také uvědomit, že efektivnost akciových trhů není konstantní, ale může se v čase měnit, poněvadž nejenže kolísá likvidita akciových trhů, ale občas také dochází $\mathrm{k}$ významným a př́lomovým změnám v investičním prostředí, což může po určitou dobu komplikovat rychlé a přesné vstřebávání zcela nových kurzotvorných informací.

Testování teorie efektivního trhu se postupně začalo zaměřovat i na méně likvidní akciové trhy. Rovněž se stalo oblíbeným tématem empirického výzkumu ve stř́edoevropském prostoru. Testy, které zkoumaly efektivnost těchto trhů v 90 . letech minulého století, ve většině případů dospívají $\mathrm{k}$ závěru, že akciové trhy se chovají neefektivním způsobem. Naopak testy z nového tisíciletí přinášejí stále více důkazů, že neefektivnost nejlikvidnějších akcií na středoevropských trzích se výrazně snížila, přičemž v některých obdobích se dokonce chovají efektivně ve slabé formě, což znamená, že ani na málo rozvinutých středoevropských akciových trzích nepřináší využívání technické analýzy výraznější prospěch při koncipování akciové strategie.

Stoupenci teorie efektivních trhů se však mohou radovat pouze částečně, poněvadž letošní Nobelovu cenu za ekonomii spolu s Famou získali současně i výrazní kritici famovského vysvětlení chování akciových trhů, a to jak představitel teorie behaviorálních financí Robert J. Shiller (Yale University), tak i Lars Peter Hansen (University of Chicago), specializující se na ekonometrické modely chování cen akciových instrumentů.

prof. Ing. Petr Musílek, Ph.D.

proděkan pro vědu a doktorské studium

Fakulta financí a účetnictví

Vysoká škola ekonomická v Praze

\footnotetext{
3 Některé studie sice identifikují ve zkoumaných časových řadách určité náznaky závislosti změn cen akciových instrumentů (statistická neefektivnost), ale ty jsou tak nepatrného rozměru, že je nelze prakticky ekonomicky využít po zohlednění vlivu transakčních nákladů a daní pro koncipování investiční strategie (ekonomická efektivnost).
} 